\title{
Influence of Spatial Comfort and Environmental Workplace Ergonomics on Job Satisfaction of Librarians in the Federal and State University Libraries in Southern Nigeria
}

\author{
Chinyere N. Ikonne, Haliso Yacob \\ Department of Information and Resources Management, Babcock University, Ilishan-Remo, Nigeria \\ Email: cikonne@yahoo.com
}

Received 23 June 2014; revised 31 July 2014; accepted 3 September 2014

Copyright (C) 2014 by authors and OALib.

This work is licensed under the Creative Commons Attribution International License (CC BY). http://creativecommons.org/licenses/by/4.0/

(c) (i) Open Access

\section{Abstract}

This study examined the influence of spatial comfort and environmental workplace ergonomics on the job satisfaction of librarians in the federal and state university libraries in Southern Nigeria. The study adopted the survey research design. The total enumeration technique was used to survey the 500 librarians from the 37 federal and state universities libraries in Southern Nigeria. Descriptive statistics was used to analyze the data collected. The findings revealed that there was a positive relationship between ergonomics (spatial comfort and environmental workplace factors) and job satisfaction. It was recommended that ergonomic measures be introduced and implemented in the design of spatial comfort and environmental workplace factors in the libraries for a greater job satisfaction of the library workforce in Nigerian University libraries.

\section{Keywords}

Ergonomics, Job Satisfaction, Spatial Comfort Designs, Environmental Workplace Factors, Nigerian University Libraries, Librarians

Subject Areas: Psychology, Sociology

\section{Introduction}

The interest in job satisfaction is much driven by the fact that experts believe that the trend of job satisfaction can affect labor market behavior. Job satisfaction is also important in that it could exert huge influence on per-

How to cite this paper: Ikonne, C.N. and Yacob, H. (2014) Influence of Spatial Comfort and Environmental Workplace Ergonomics on Job Satisfaction of Librarians in the Federal and State University Libraries in Southern Nigeria. Open Access Library Journal, 1: e814. http://dx.doi.org/10.4236/oalib.1100814 
formance, retention, and employee turnover and absenteeism. It has been shown that the ability of any organization to achieve its goals depends on its capability to attract, retain, and even maintain competent and satisfied staff in its employment. According to [1], every organization that has goals to achieve should have satisfied and happy staff.

Ergonomics is concerned with designing and arranging facilities and structures so that people can use them effectively and safely. According to [2] and [3], the major aim of ergonomics is to ensure that there is a good fit between workers and their jobs, and this, in turn, leads to achieving a higher level of worker's comfort, safety and health, productivity, and efficiency. [4] opines that workplace environment in a majority of the industries is described as unsafe and unhealthy for the fact that there are poorly designed workstations, unsuitable furniture, lack of ventilation, inappropriate lighting, excessive noise, insufficient safety measures in fire emergencies as well as of personal protective equipment. These factors could make work environment uncomfortable and stressful, which could adversely affect the quality of workers' performance and, in turn, lead to job dissatisfaction.

The functions of librarians in the University are very vital as they are to assist the faculty and students in assessing much needed knowledge. Therefore, for effective performance and attainment of job satisfaction, it is necessary that librarians work in comfortable and healthy designed libraries. In view of this, [5] observes that many researchers have suggested a number of workplace design strategies to improve the quality of the work environment. A part of these designs are spatial comfort (workplace and workspace designs) and workplace environment designs which are aspects of ergonomic factors that aim at increasing satisfaction among employees.

\section{Statement of the Problem}

Spatial comfort and environmental workplace designs are aspects of ergonomic designs in the workplace that are very important in achieving comfort, job satisfaction, and improved quality of life. Conversely, improper workplace environment designs and unsuitable working conditions that could cause or aggravate unhealthy conditions have been associated with perceived adverse effects on health. With the awareness and appreciation benefits of implementation of ergonomics, some organizations and libraries have adopted the application of these ergonomic measures thereby improving job satisfaction. However, in the case of Nigerian University libraries, evidence shows that they are lagging behind in adopting these measures. As a result, Nigerian University library employees are undergoing some ergonomic difficulties that could negatively influence their job satisfaction. It is in this light that this study investigated the influence of spatial comfort and environmental workplace ergonomic design on the job satisfaction of librarians in the federal and state university libraries in Southern Nigeria.

\section{Objective of the Study}

The objective of this study was to survey the relationship between spatial comfort and work environmental designs on the job satisfaction of librarians in the federal and state university libraries in Southern Nigeria. The specific objectives were to:

1) establish whether the spatial comfort (environmental workplace and workspace) designs have any influence on the job satisfaction of the librarians, and

2) ascertain if the environmental workplace factors (light, noise and ventilation) have any influence on the job satisfaction of the librarians.

\subsection{Hypotheses}

1) H1: There is no significant relationship between the spatial comfort (environmental workplace and workspace) designs and job satisfaction of the librarians.

2) H2: There is no significant relationship between environmental workplace factors (light, noise and ventilation) and the job satisfaction of the librarians.

\subsection{Review of Literature}

Workplace designs comprise suitable workstations and equipment design and chairs, adequate workspace design (elements of furniture layouts and arrangement, acoustic privacy, space that supports face-to-face confidential discussions, workspace supports for work needs, adjustability of workspace to fit the need for work surface, sto- 
rage, etc.), and physical work environment—good ventilation, appropriate lighting, noise free, calm and clean work environment [6].

\subsection{Spatial Comfort Designs}

Spatial comfort designs (workplace environmental designs) are among the key factors that determine how satisfied and motivated workers would feel in the workplace. [4] points out that the majority of the industries are described as unsafe and unhealthy for the fact that there are poorly designed workstations, unsuitable furniture, lack of ventilation, inappropriate lighting, excessive noise, insufficient safety measures in fire emergencies, and lack of personal protective equipment. However, [7] report that studies reveal that workers who are comfortable with their work environment have the tendency of generating better work. This is so because their physical environment positively affects their job perception, attitudes, and job satisfaction. Similarly, [8] examined the impact of the spatial qualities of the workplace on architects' job satisfaction in Belfast, and they discovered that their job satisfaction has been rated to be relatively high. They identified factors such as control over thermal conditions, acoustics, views, lighting, and ergonomics as particularly significant determinants of job satisfaction.

The studies of [9] have revealed that as a result of proper workspace design, workers' satisfaction increased. For instance, [10] survey on the US workplace environment showed that eighty-nine percent (89\%) blamed their working environment for their job dissatisfaction, and almost ninety percent (90\%) of the survey respondents believed that better workplace design and layout result in better overall employee performance. [11] survey of 2000 employees showed that nine out of ten indicated that an appropriate workspace quality positively affects the attitude of employees and increases their productivity.

According to [12], privacy and individuality are key motivational desires in relation to workspace. [13] have noted that several studies have also revealed that office workers are dissatisfied and uncomfortable with the open plan because noise is a dominant disturbing force in the open plan office environment. Investigations by [14] and [15] have found that when people move out of their private enclosed offices into open workstations, they feel negative about it, feel lack of privacy, and perceive problems of confidentiality. [16] also discovered in their study that approximately eighty percent (80\%) of office workers say that the fact that others hear their private conversation is a problem for them.

\subsection{Environmental Workplace Factors}

Regarding external workplace factors, [17] claims that there are many factors that can make up one's work environment. These factors include temperature, humidity, heat and cold, ventilation, lighting, vibration, gases, air pressure and gravity. These are perceived to have effect on the health, comfort and the performance of employees and, therefore, could be considered as major sources of comfort or otherwise in the workplace.

First, light and illumination are some of the work comfort factors that have been indentified to either cause job satisfaction or dissatisfaction. Lighting is one of the key elements of ergonomics in the workplace. It influences the personal well-being and health and health and also acts as a positive impact on motivation and performance. [18] states that lighting is needed to help employees in maintaining and generating their visual tasks. There must be sufficient light in the workplace to ensure the safety of every worker. Poor lighting creates visual problems for the employees which, in turn, results in visual fatigue and discomfort, neck and back pain, especially if the worker adopts a poor posture, and particularly when having to constantly lean forward to see the work, [19].

[20] point out that there are specifications for reading and working areas because different activities require different levels of light. Improvements in lighting according to ergonomic principles should ensure the provision of light that will suit the different levels of light activities over the entire work area. In general, the more detailed the task, the greater the light requirement. The more complex the visual task, the higher the illuminance is requested. Also, working in dim or over-bright work environments can result in eyestrain, headaches, irritability and, inevitably, reduced productivity and satisfaction. In their study of some software engineers, [21] discovered that improvements in lighting and workplace design, by applying ergonomic principles, reduced their visual discomfort, shoulder and neck pains. Hence, good lighting is required for good visibility of the environment.

Noise is considered as a primary source of an environmental stressor and an intermittent noise is seen to be the most disturbing forms of noise [22]. Noise is also regarded as a source of distraction, frustration and ultimately stress amongst office workers. Prolonged noise in the workplace could contribute to the development of 
diabetes, [23]. Further, [24] state that noise has been perceived to have been linked to physiological problems such as hypertension, heart irregularities, digestive disorders, extreme fatigue, ulcers, allergies, fears, and neurological disorders.

According to [25], noise can also lead to higher incidents of illness, absenteeism and employee turnover which eventually have a negative effect on an organization's performance and growth. [16] conducted a study at the Centre for the Built Environment (CBE) at the University of California, Berkeley, which involved 23,450 respondents from 142 buildings. The study revealed that the occupants of private offices were significantly more satisfied with noise levels and speech privacy than occupants in open plan office.

Finally, concerning ventilation, [26] posit that ventilation is the process by which outdoor recycled air is introduced and distributed into a building or a room. Ventilation is necessary to remove indoor-generated pollutants from indoor air. It has been observed that ventilation has a significant impact on several important human outcomes such as communicable respiratory illnesses, sick building syndrome symptom, task performance and productivity, perceived air quality and respiratory allergies and asthma, [27]. Health effects potentially related to poor indoor air pollutants in office environments may include flu like symptoms, dermatitis, irritation, systemic toxicity, headache, fatigue, chest tightness, [28] [29] which according to [30] could have acute and semi-acute effects and longer term based effects. Poor indoor air quality in buildings can decrease productivity as well as cause workers and visitors to express dissatisfaction, [31]. In addition, poor indoor air quality, according to [32], could likely affect individuals' wellbeing, which could lead to workers taking a long break, increase in complaints and sick leave, mistakes and risks of accidents at work. The report of [33] is that there is evidence that better physical health is correlated with higher job satisfaction and other factors such as lower job stress and better psychological well-being.

\section{Methodology}

The research design adopted for this study was descriptive survey. Thirty-seven (37) University libraries were involved in the study (Table 1). A total enumeration sampling technique was used to survey the responses of all the 500 librarians who work in the federal and state university libraries in Southern Nigeria. A structured questionnaire was the instrument used for data collection. The option of choices followed the pattern of a 4-point scale: from 1 -strongly disagree to 4 -strongly agree $(1=$ low and $4=$ high). The data collected were analyzed using descriptive statistics of frequency count, percentage, mean and standard deviation.

\section{Presentation of Findings}

Table 2 reveals the distribution of respondents based on their gender as well as their educational qualification. The table revealed that there were 189 women (53.7\%) while the male respondents were 163 (46.3\%). Regarding educational qualification, the study showed that the major percentage of the respondents $(40.3 \%)$ were MLS/MLIS (Masters in Library Science/Masters in Library and Information Science) degree holders while 34.7\% were BLS/BLIS (Bachelor in Library Science/Bachelor in Library and Information Science) holders. About 3.7\% were MSc. Inf (Master in Science Information) degree holders, 2.3\% were Ph.D holders, while 1.1\% and $0.3 \%$ were BIRM (Bachelor in Information Resources Management) and MIRM (Masters in Information Recourses Management) degree holders respectively. About eighteen percent (17.6\%) indicated their education qualification as "others".

Research Question One: What are spatial comfort (environmental workplace and workspace) design factors that could have influence on the job satisfaction of librarians?

Table 3 shows that the respondents were satisfied with having a closed office for my privacy (mean $=2.86$ ), followed by workspace design that allows social interaction between me and other workers (mean $=2.81$ ), workplace in an undisturbed environment for work concentration (mean $=2.68$ ), and workplace should be open enough so I can see my colleagues working (mean $=2.66$ ).

This corroborates the findings of [7] who argued that workers who are comfortable with their working environment have the tendency of generating better work as their physical environment positively affects their job perception, attitudes, and job satisfaction. The findings of [8] also conveyed a similar result that the spatial qualities of the workplace positively influence job satisfaction. [10] study buttresses these findings as he discovered that workers in the US blame their working environment (spatial comfort) for their lack of job satisfaction.

Several studies have also provided evidence that office workers are uncomfortable in open plan configura- 
Table 1. List of federal and state universities/libraries in the Southern Nigeria.

\begin{tabular}{|c|c|c|}
\hline State & Federal University Library & State University Library \\
\hline Abia & Micheal Okpara University of Agiculture, Umudike & Abia State University,Uturu \\
\hline Akwa Ibom & University Of Uyo, Uyo & Akwa-Ibom State University Of Technology, Uyo \\
\hline Anambra & Nnamdi Azikiwe University, Awka & Anambra State University of Science and Technology, Uli \\
\hline Bayelsa & Niger Delta University,Yenagoa & Federal University, Otuoke, Bayelsa \\
\hline Cross River & University of Calabar, Calabar & Cross River State University and Technology, Calabar \\
\hline Delta & Federal University of Petroleum Resources, Effurun & Delta State University, Abraka \\
\hline Ebonyi & Federal University, Ndufu-Alike & Ebonyi State University, Abakaliki \\
\hline Edo & University of Benin, Benin City & Ambrose Alli University, Ekpoma \\
\hline Ekiti & Federal University, Oye-Ekiti & Ekiti State University, Ado Ekiti \\
\hline Enugu & University of Nigeria, Nsukka & Enugu State University of Science and Technology, Enugu \\
\hline Imo & Federal University of Technology, Owerri & Imo State University, Owerri \\
\hline Lagos & University of Lagos & Lagos State University, Lagos \\
\hline Ogun & $\begin{array}{l}\text { Olabisi Onabanjo Universiy, Ago Iwoye } \\
\text { University of Agriculture, Abeokuta }\end{array}$ & Tai Solarin University of Education, Ijebu-Ode \\
\hline Ondo & Federal University of Technology, Akure & $\begin{array}{l}\text { Ondo State University of Science and Technology, Okitipupa } \\
\text { Adekunle Ajasin University, Akungba }\end{array}$ \\
\hline Osun & Obafemi Awolowo University, Ile-Ife & Ladoke Akintola University of Technology, Ogbomoso \\
\hline Oyo & University of Ibadan, Ibadan & Osun State University, Oshogbo \\
\hline \multirow[t]{3}{*}{ Rivers } & University of Port Harcourt, Port Harcourt & $\begin{array}{l}\text { Rivers State University of Science and Technology } \\
\text { Ignatius Ajuru University of Education, Rumuolumeni }\end{array}$ \\
\hline & 18 & 19 \\
\hline & Overall total & 37 universities \\
\hline
\end{tabular}

Table 2. Demographic characteristics of respondents.

\begin{tabular}{|c|c|c|c|}
\hline \multicolumn{2}{|c|}{ Demographic information } & \multicolumn{2}{|c|}{ Study sample } \\
\hline Character & Information & Frequency & Percentage \\
\hline \multirow{3}{*}{ Gender } & Male & 163 & 46.3 \\
\hline & Female & 189 & 53.7 \\
\hline & Total & 352 & 100.0 \\
\hline \multirow{8}{*}{ Educational qualification } & BLS/BLIS & 122 & 34.7 \\
\hline & BIRM & 4 & 1.1 \\
\hline & MLS/MLIS & 142 & 40.3 \\
\hline & MSC. Inf & 13 & 3.7 \\
\hline & MIRM & 1 & .3 \\
\hline & $\mathrm{PhD}$ & 8 & 2.3 \\
\hline & Others & 62 & 17.6 \\
\hline & Total & 352 & 100.0 \\
\hline
\end{tabular}


Table 3. Spatial comfort (workplace and workspace) designs and job satisfaction.

\begin{tabular}{|c|c|c|c|c|c|c|}
\hline Statement & VD (\%) & DS (\%) & $\mathrm{S}(\%)$ & VS (\%) & MEAN & SD \\
\hline I prefer having a closed office for my privacy. & $24(6.8)$ & $87(24.7)$ & 15744.6 & $84(23.9)$ & 2.86 & 0.860 \\
\hline $\begin{array}{l}\text { My workspace design allows social interaction between me } \\
\text { and other workers. }\end{array}$ & $21(6.0)$ & $75(21.3)$ & $206(58.5)$ & $50(14.2)$ & 2.81 & 0.748 \\
\hline $\begin{array}{l}\text { My workplace is in an undisturbed environment where I } \\
\text { can concentrate on my work. }\end{array}$ & $40(11.4)$ & $85(24.1)$ & $176(50.0)$ & $51(14.5)$ & 2.68 & 0.859 \\
\hline $\begin{array}{l}\text { My workplace should be open enough so I can see my } \\
\text { colleagues working. }\end{array}$ & $21(6.0)$ & $114(32.4)$ & $181(51.4)$ & $36(10.2)$ & 2.66 & 0.742 \\
\hline $\begin{array}{l}\text { I am able to control my environment as a result of my } \\
\text { workspace design. }\end{array}$ & $24(6.8)$ & $124(35.2)$ & $164(46.6)$ & $40(11.4)$ & 2.63 & 0.774 \\
\hline I share my workspace with many colleagues. & $55(15.6)$ & $86(24.4)$ & $144(40.9)$ & $67(19.0)$ & 2.63 & 0.963 \\
\hline $\begin{array}{l}\text { My workstation is positioned to avoid glare and reflection } \\
\text { from light. }\end{array}$ & $40(11.4)$ & $116(33.0)$ & $158(44.9)$ & $38(10.8)$ & 2.55 & 0.832 \\
\hline My workspace is adequate for all my workstation equipment. & $34(9.7)$ & $131(37.2)$ & $156(44.3)$ & $31(8.8)$ & 2.52 & 0.788 \\
\hline My workspace is adequate for me to perform all tasks. & $32(9.1)$ & $141(40.1)$ & $142(40.3)$ & $37(10.5)$ & 2.52 & 0.802 \\
\hline $\begin{array}{l}\text { My workplace serves multi-purpose functions for scheduled } \\
\text { and instant meetings. }\end{array}$ & $33(9.4)$ & $133(37.8)$ & $162(46.0)$ & $24(6.8)$ & 2.50 & 0.759 \\
\hline $\begin{array}{l}\text { My workspace design gives me the opportunity to control } \\
\text { the degree of my access of other workers. }\end{array}$ & $46(13.1)$ & $141(40.1$ & $135(38.4)$ & $30(8.5)$ & 2.42 & 0.823 \\
\hline I have enough privacy in my workspace. & $86(24.4)$ & 111 (31.5) & 123 (34.9) & $32(9.1)$ & 2.29 & 0.937 \\
\hline I prefer sharing office with other colleagues. & 70 (19.9) & $142(40.3)$ & 110 (31.3) & $30(8.5)$ & 2.28 & 0.880 \\
\hline
\end{tabular}

tions and would prefer private enclosed workspace [14] and [13]. Findings from [12] testified that privacy and individuality are key motivational desires in relation to workspace. [13] found in their various studies that office workers are dissatisfied and uncomfortable with the open plan office and would rather prefer having their private offices (closed office). In view of this, [34] cautioned that employers should not neglect providing adequate workspaces so as to maintain and retain their workers.

Research Question Two: What are the ways through which environmental workplace factors (light, noise and ventilation) could have influence on the job satisfaction of librarians?

Table 4 indicates that the respondents were satisfied with having windows in my office (mean $=2.99$ ), followed by cross-ventilation in my office (mean $=2.74$ ), the lighting for my workspace is appropriate (mean = 2.73), work environment is quiet enough for me to work well (mean $=2.70$ ), and illumination level is bright enough for my visual need (mean $=2.67$ ).

[35], [36] and [37] studies elucidated that there are relationships between the physical environment and satisfaction with lighting, ventilation, and privacy and acoustics. Consequently, they found out that overall environment satisfaction could predict job satisfaction. Therefore, these findings corroborate those of [38], who studied the Cost-effective Open-Plan Environments (COPE) project, using survey data from 779 participants in nine buildings, that revealed that there is a link between job satisfaction and lighting, ventilation, privacy and acoustics, and with overall environmental satisfaction.

Poor lighting creates visual problems such as visual fatigue and discomfort, neck and back pains. It is on this basis that [18] confirmed that good lighting is needed to help employees in generating and maintaining their visual tasks. In addition, for optimum performance of visual tasks (and satisfaction) adequate light without glare and blinding should be provided. In the study of [39] where they examined the amount of exposure that workers have to noise in order to determine any evidence of habituation, it was found that the respondents reported having concentration impairment from various components of office noise. [31] acknowledged the importance of good ventilation because poor indoor air quality in buildings can decrease productivity as well as cause workers and others to express dissatisfaction. Based on this, [32] concluded that poor ventilation has the tendency of affecting individuals' wellbeing.

Hypothesis One: There is no significant relationship between spatial comfort designs (workplace and workspace) and the job satisfaction of the librarians.

Table 5 shows the relationship between spatial comfort (environmental workplace and workspace) designs 
Table 4. Environmental workplace factors (light, noise and ventilation) and job satisfaction.

\begin{tabular}{|c|c|c|c|c|c|c|}
\hline Statement & VD (\%) & DS ( $\%)$ & S (\%) & VS (\%) & MEAN & SD \\
\hline There are windows in my office. & $28(8.0)$ & 37 (10.5) & 198 (56.3) & 89 (25.3) & 2.99 & 0.823 \\
\hline There is always cross-ventilation in my office. & $36(10.2)$ & $82(23.3)$ & 172 (48.9) & $62(17.6)$ & 2.74 & 0.867 \\
\hline The lighting for my workspace is appropriate. & 35 (9.9) & $90(25.6)$ & $161(45.7)$ & $66(18.8)$ & 2.73 & 0.879 \\
\hline $\begin{array}{l}\text { My work environment (office) is quiet enough for me to } \\
\text { work well. }\end{array}$ & $38(10.8)$ & $89(25.3)$ & $166(47.2)$ & $59(16.8)$ & 2.70 & 0.874 \\
\hline The illumination level is bright enough for my visual need. & $40(11.4)$ & 89 (25.3) & $171(48.6)$ & $52(14.8)$ & 2.67 & 0.864 \\
\hline Because of the windows, the air quality is always fresh. & $44(12.5)$ & $99(28.1)$ & $141(40.1)$ & $68(19.3)$ & 2.66 & 0.929 \\
\hline $\begin{array}{l}\text { The noise level around my workplace does not affect } \\
\text { my communication with others. }\end{array}$ & $36(10.2)$ & 104 (29.5) & $166(47.2)$ & $46(13.1)$ & 2.63 & 0.837 \\
\hline I am satisfied with the temperature of my workplace. & $52(14.8)$ & $84(23.9)$ & $163(46.3)$ & $53(15.1)$ & 2.62 & 0.914 \\
\hline Noise from my colleagues does not disturb me. & $39(11.1)$ & 103 (29.3) & 170 (48.3) & $40(11.4)$ & 2.60 & 0.831 \\
\hline $\begin{array}{l}\text { Sun rays from my window are needed for adequate } \\
\text { illumination of my workstation. }\end{array}$ & $36(10.2)$ & $121(34.4)$ & $147(41.8)$ & $48(13.6)$ & 2.59 & 0.849 \\
\hline $\begin{array}{l}\text { The level of noise in my workplace does not affect my } \\
\text { privacy. }\end{array}$ & $42(11.9)$ & $114(32.4)$ & $157(44.6)$ & $39(11.1)$ & 2.55 & 0.843 \\
\hline I am satisfied with the level of noise is my office. & $61(17.3)$ & $103(29.3)$ & $145(41.2)$ & $43(12.2)$ & 2.48 & 0.918 \\
\hline There is constant light in my workplace. & $74(21.0)$ & $101(28.7)$ & 119 (33.8) & $58(16.5)$ & 2.46 & 10.001 \\
\hline I am able to control the temperature in my workplace. & $69(19.6)$ & 107 (30.4) & $136(38.6)$ & $40(11.4)$ & 2.42 & 0.930 \\
\hline Task lights are provided when necessary. & $59(16.8)$ & $129(36.6)$ & $124(35.2)$ & $40(11.4)$ & 2.41 & 0.898 \\
\hline There is much heat in my office. & $87(24.7)$ & 138 (39.2) & $89(25.3)$ & $38(10.8)$ & 2.22 & 0.941 \\
\hline The only source of fresh air is the conditioner. & $101(28.7)$ & $159(45.2)$ & $67(19.0)$ & $25(7.1)$ & 2.05 & 0.873 \\
\hline
\end{tabular}

Table 5. Relationship between the spatial comfort (workplace and workspace) designs and job satisfaction of librarians.

\begin{tabular}{ccccccc}
\hline Variables & N & Mean & Std. deviation & R & Sig. & Remark \\
\hline Job satisfaction & 352 & 2.70 & 0.43 & 0.47 & 0.000 \\
Spatial comfort designs & 352 & 2.57 & 0.42 & Significant \\
\hline
\end{tabular}

and job satisfaction of librarians in the federal and state university libraries in Southern Nigeria. Results of the analysis provide adequate evidence to reject the null hypothesis. It therefore follows that there is a significant positive relationship between spatial comfort (environmental workplace and workspace) designs and job satisfaction of librarians in the federal and state university libraries in Southern Nigeria $(r=0.47, \mathrm{P}<0.05)$. This, therefore, indicates that factors such as adequate environmental workplace and workspace designs are necessary in attaining job satisfaction.

Hypothesis Two: There is no significant relationship between environmental workplace factors (light, noise and ventilation) and job satisfaction of librarians.

Table 6 presents the results of the analysis showing the relationship between environmental workplace factors (light, noise and ventilation) and librarians' job satisfaction in federal and state university libraries in Southern Nigerian. The result showed that there is a significant positive relationship between environmental workplace factors (light, noise and ventilation) and librarians' job satisfaction ( $r=0.36, \mathrm{P}<0.05$ ). Therefore, the null hypothesis is rejected. The implication here is that the more the ergonomic problems of light, noise, ventilation are resolved, the more the librarians will have achieved job satisfaction.

\section{Conclusions and Recommendations}

The aim of this study was to assess the influence of spatial comfort and environmental workplace ergonomic designs on the job satisfaction of librarians in the federal and state university libraries in Southern Nigeria. Hardly can the importance of job satisfaction be over emphasized as it has a significant influence on job-related behaviors such as productivity, absenteeism, turnover rates, retention, and other employee relations. So, this study 
Table 6. Relationship between environmental workplace factors (light, noise and ventilation) and job satisfaction of the librarians.

\begin{tabular}{ccccccc}
\hline Variables & N & Mean & Std. deviation & R & Sig. & Remark \\
\hline Job satisfaction & 352 & 2.70 & 0.43 & 0.36 & 0.000 \\
Environmental workplace factors & 352 & 2.56 & 0.47 & & \\
\hline
\end{tabular}

has revealed that spatial comfort and environmental workplace designs are aspects of ergonomic factors that have significant contribution in the attainment of job satisfaction for the librarians in the federal and state universities in Southern Nigeria.

The study, therefore, recommends that the University management should collaborate with the University Library management in introducing and implementing ergonomic measures in the design of spatial comfort and environmental workplace factors in the libraries for a greater job satisfaction of the library workforce and the attendant of higher performance and productivity. They should ensure that they provide private workplace and workspace designs as indicated by the librarians. This could motivate higher job performance and satisfaction among the University librarians. In addition, the more the ergonomic problems of light, noise, and ventilation are resolved, the better they will positively influence the well-being and the health of the federal and state university librarians and this will lead to a higher work motivation, productivity and job satisfaction.

\section{References}

[1] Oshagbemi, T. (2000) How Satisfied Are Academics with Their Primary Tasks of Teaching Research and Administration and Management. International Sustainable in Higher Education, 1, 124-136. http://dx.doi.org/10.1108/1467630010371876

[2] Ghosh, S., Bagchi, A., Sen, D. and Bandyopadhyay, P. (2011) Ergonomics: A Bridge between Fundamentals and Applied Research. Indian Journal of Occupational and Environmental Medicine, 15, 14-17. http://dx.doi.org/10.4103/0019-5278.83000

[3] Azadeha, A., Saberib, M. and Rouzbahmana, M. (2009) Utilization of an Artificial Intelligence Approach for Assessment of Job Satisfaction. International Journal of Intelligent Information Technology Application, 2, 250-255.

[4] Chandrasekar, K. (2011) Workplace Environment and Its Impact on Organizational Performance in Public Sector Organizational. International Journal of Enterprise Computing and Business Systems. http://www.ijecbs.com/January2011/N4Jan2011.pdf

[5] Nadin, S.J., Waterson, P.E. and Parker, S.K. (2001) Participation in Job Redesign: In Evaluation of the Use of a Socio Technical Tool and Its Impact. Human Factor and Ergonomics in Manufacturing, 11, 53-69. http://dx.doi.org/10.1002/1520-6564(200124)11:1<53::AID-HFM4>3.0.CO;2-F

[6] O’Neill, R. (2005) Standing Problem. Hazards Magazine. http://www.hazards.org/standing/

[7] Lee, S.Y. and Brand, G.L. (2005) Effects of Control over Office Workspace on Perceptions of the Work Environment and Work Outcomes. Journal of Environmental Psychology, 25, 323-333. http://dx.doi.org/10.1016/j.jenvp.2005.08.001

[8] Salama, A.M. and Courtney, L. (2013) The Impact of the Spatial Qualities of the Workplace on Architects’ Job Satisfaction. International Journal of Architectural Research. http://archnet.org/library/documents/one-document.jsp?document_id=13526

[9] Huang, Y.H., Robertson, M.M. and Chang, K.I. (2004) The Role of Environmental Control on Environmental Satisfaction, Communication, and Psychological Stress; Effects of Office Ergonomics Training. Environment and Behavior, 36, 617-637. http://dx.doi.org/10.1177/0013916503262543

[10] (2006) Gensler Design + Performance Index. The U.S. Workplace Survey. www.gensler.com

[11] Hughes, J. (2007) Office Design Is Pivotal to Employee Productivity. San Diego Source the Daily Transcript.

[12] Timoteo-Afinidad, C.B. (2010) Workstation and Workspace Ergonomics in Philippine Libraries: An Emerging Priority. Journal of Philippine Librarianship, 30, 21-44.

[13] Fried, Y., Slowik, L.H., Ben-David, H.A. and Tiegs, R.B. (2001) Exploring the Relationship between Workspace Density and Employee Attitudinal Reactions: An Integrative Model. Journal of Occupational and Organizational Psychology, 74, 259-372. http://dx.doi.org/10.1348/096317901167406

[14] Brennan, A., Chugh, J.S. and Kline, T. (2002) Traditional versus Open Office Design: A Longitudinal Study. Environment and Behavior, 34, 279-299. http://dx.doi.org/10.1177/0013916502034003001

[15] Rishi, P., Sinha, S.P. and Dubey, R. (2000) A Correlational Study of Workplace Characteristics and Work Satisfaction 
among Indian Bank Employees. Psychologia, 43, 155-164.

[16] Jensen, K.L., Arens, E. and Zagreus, L. (2005) Acoustical Quality in Office Workstations, as Assessed by Occupant Surveys. Indoor Air, 2401-2405.

[17] Parsons, K.C. (2000) Environmental Ergonomics: A Review of Principles, Methods and Models. Journal of Applied Ergonomics, 31, 581-594. http://dx.doi.org/10.1016/S0003-6870(00)00044-2

[18] Bachner, J.P. (2000) Quality Lighting Means Quality Work. Quality Progress, 33, 67-71.

[19] Industrial Accident Prevention Association, IAPA (2008) http://www.iapa.ca/pdf/lightin.pdf

[20] Chandra, A.M., Ghosh, S., Barman, S. and Chakravarti, D.P. (2009) Ergonomics Issues in Academic Libraries in Kolkata, West Bangal: A Pilot Study. Library Philosophy and Practice. http://www.webpages.uidaho.edu/ mbolin/chandra-ghosh.pdf

[21] Aaras, A., Horgen, G. and Helland, M. (2001) Can Visual Discomfort Influence on Muscle Pain for Visual Display Unit (VDU) Workers? 1-4. http://www.nordiskergonomi.org/nes2007/CD_NES_2007/papers/S3-2_Aaraas.pdf

[22] Szalma, J.L. and Hancock, P.A. (2011) Noise Effects on Human Performance: A Meta-Analytic Synthesis. Psychological Bulletin, 137, 682-707. http://www.ncbi.nlm.nih.gov/pubmed/21707130 http://dx.doi.org/10.1037/a0023987

[23] Oomen, V.G., Knowles, M. and Zhao, I. (2008) Should Health Service Managers Embrace Open-Plan Work Environments? A Review. Asia Pacific Journal of Health Management, 3, 37-43.

[24] Engel, Z., Augustynska, D., Koton, J. and Kacmarska, A. (2006) Noise: Definitions. In: Karwowski, W., Ed., International Encyclopedia of Ergonomics and Human Factors, CRC, Boca Raton.

[25] Abbot, D. (2004) Calming the Office Cacophony. The Safety and Health Practitioner, 22, 34-36.

[26] Etheridge, D.W. and Sandberg, M. (1996) Building Ventilation-Theory and Measurement. John Wiley \& Sons, Chichester.

[27] Seppänen, O.A. and Fisk, W.J. (2004) Summary of Human Responses to Ventilation. Indoor Air, 14, 102-118. http://dx.doi.org/10.1111/j.1600-0668.2004.00279.x

[28] Hess-Kosa, K. (2002) Indoor Air Quality: Sampling Methodologies. Lewis Publishers, Manchester.

[29] Huang, Y.H., Robertson, M.M. and Chang, K.I. (2004) The Role of Environmental Control on Environmental Satisfaction, Communication and Psychological Stress: Effects of Office Ergonomics Training. Environment and Behavior, 36, 617-637.

[30] Carrer, P. and Muzi, G. (2011) Ventilation, Sick Building Syndrome: Role of Occupational Health Services in the Assessment and Management of Indoor Air Quality Problems. Giornale Italiano di Medicina del Lavoro ed Ergonomia, 33, 192-194.

[31] Wyon, D.P. (2004) The Effects of Indoor Air Quality on Performance and Productivity. Indoor Air, 14, 92-101. http://dx.doi.org/10.1111/j.1600-0668.2004.00278.x

[32] Mahbob, N.S., Kamaruzzamani, S.N., Salleh, N. and Sulaiman, R. (2011) A Correlation Studies of Indoor Environmental Quality (IEQ) towards Productive Workplace. Proceedings of the 2nd International Conference on Environmental Science and Technology, Antalya, 14-17 May 2014.

[33] Cass, M.H., Siu, O.L., Faragher, E.B. and Cooper, C.L. (2003) A Meta-Analysis of the Relationship between Job Satisfaction and Employee Health in Hong Kong. Stress and Health, 19, 79-95. http://dx.doi.org/10.1002/smi.959

[34] Miller, H. (2008) Home Sweet Office: Comfort in the Workplace. Herman Miller, Inc., Zeeland.

[35] Veitch, J.A., Charles, K.E., Newsham, G.R., Marquardt, C.J.G. and Geerts, J. (2003) Environmental Satisfaction in Open-Plan Environments: 5. Workstation and Physical Condition Effects. Report No. IRC-RR-154, National Research Council of Canada, Institute for Research in Construction, Ottawa.

http://www.google.com/url?sa=t\&rct=j\&q=\&esrc=s\&source=web\&cd=15\&cad=rja\&uact=8\&ved=0CDgQFjAEOAo\& url=http\%3A\%2F\%2Fwww.ibrarian.net\%2Fnavon\%2Fpaper\%2FEnvironmental_Satisfaction_in_Open_Plan_Environ me.pdf\%3Fpaperid\%3D6453274\&ei=17oRVJGzDsGUgwT034CYDg\&usg=AFQjCNF7DFJ0rIGW2fOEn6wdVi_34 M2nJA\&bvm=bv.74894050,d.cWc

[36] Veitch, J.A., Charles, K.E., Newsham, G.R., Marquardt, C.J.G. and Geerts, J. (2004) Workstation Characteristics and Environmental Satisfaction in Open-Plan Offices: COPE Field Findings (NRCC-47629). National Research Council, Ottawa.

[37] Veitch, J.A., Geerts, J., Charles, K.E., Newsham, G.R. and Marquardt, C.J.G. (2005) Satisfaction with Lighting in Open-Plan Offices: COPE Field Findings. Proceedings of Lux Europa, 10th European Lighting Conference, Berlin, 19-21 September 2005, 414-417. http://archive.nrc-cnrc.gc.ca/obj/irc/doc/pubs/nrcc48164/nrcc48164.pdf

[38] Veitch, J.A., Charles, K.E., Farley, K.M.J. and Newsham, G.R. (2007) A Model of Satisfaction with Open-Plan Office 
Conditions: COPE Field Findings. Journal of Environmental Psychology, 27, 177-189.

http://dx.doi.org/10.1016/j.jenvp.2007.04.002

[39] Banbury, S.P. and Berry, D.C. (2005) Office Noise and Employees Concentration: Identifying Causes of Disruption and Potential Improvements. Ergonomics, 48, 25-37. http://dx.doi.org/10.1080/00140130412331311390 